\title{
Perubahan dan Kontinuitas Pola Spasial pada Rumah Tinggal Cina \\ PERUBAHAN DAN KONTINUITAS POLA SPASIAL PADA RUMAH TINGGAL CINA DI SODITAN, KARANGTURI, DAN BABAGAN, LASEM
}

The study would analyze some factors underlying the spatial changes on Chinese houses and interprets what has influenced them. The focusing of study is interacting the Chinese houses's layout from Soditan, Karangturi, and Babagan that has different periods. The study based on the field observation and in-depth interview has done in June 2004 is used to analyze Chinese houses in Lasem. There is no hypothesis, this study is to increase understanding of the spatial pattern on Chinese houses where has gone through in life's changes. Spatial Syntax is used for analysis and interpretation of Chinese houses's layout. The spatial pattern was found by interacting the irreducible objects and related to each other on human spatial organization in all its variability. This part would discuss factor which implicate the changes of spatial pattern on Chinese houses in Soditan, Karangturi, and Babagan. The analysis generally found that first, the changing of time periods no implicate to spatial pattern on Chinese houses in Lasem. There has still keeped of using main spatial pattern on their layout. Second, the changing orientation of Chinese houses from river to roads has no influenced the spatial pattern. Third, the changes of space just has been reducing space from high complexity to be more simplicity. Regularity spatial pattern on Chinese houses is the main spatial pattern that always on ringness dimension which are six spaces : front courtyard, front terrace, praying room (Ngetiya), living room, back terrace, and back courtyard. The pattern shows in a symmetric and distributed relationship, the higher hieararchi of space is located in living room (space F).

Keyword: spatial pattern, chinese house

Lasem satu kota di pesisir utara pulau Jawa merupakan salah satu kota pelabuhan yang cukup besar pada masanya. Selain itu Lasem juga menjadi ibukota suatu kerajaan yang besar. Kerajaan Lasem menurut Negarakertagama adalah salah satu dari anak kerajaan Majapahit. Kerajaan Lasem dipimpin saudara sepupu Hayam Wuruk, Dewi Indu atau Bhre Lasem (Hutama, 1999).

Lokasinya yang terletak di pesisir menjadikan Lasem sebagai kota yang mengalami transisi sosial budaya. Menurut Hutama (1999) terdapat dua pola kebudayaan yang cukup besar pada masanya yaitu Hindu dan Islam. Dengan fungsinya sebagai ibukota sekaligus kota pelabuhan. Lasem mempunyai dua nukleus permukiman. Di pesisir, yaitu di daerah
Caruban dan di pedalaman dengan pusatnya pada sekitar alun-alun.

Permukiman bangsawan lokasinya berseberangan dengan permukiman Cina yang pada waktu itu banyak yang beragama Islam terletak di sebelah barat sungai Lasem. Masuknya Islam di Lasem mengubah pola sosial budaya setempat. Perubahan ini juga terjadi pada masyarakat Cina di tepi sungai Lasem. Menurut catatan klenteng Sam Po Kong antara tahun $14501475 \mathrm{M}$ telah banyak tinggal masyarakat Cina yang menganut agama Konghucu di Jawa sehingga banyak masjid-masjid yang diubah menjadi klenteng,

\footnotetext{
*Korespondensi penulis dialamatkan ke Program Studi Desain Interior, Fakultas Seni Rupa, Institut Seni Indonesia Yogyakarta, Tel/Fax: +62 274417219 e-mail: yulyta_kodrat@yahoo.co.uk
} 
salah satunya di Lasem (de Graaj \& Pigeaud dalam Hutama, 1999). Sungai Lasem tetap menjadi tempat berlangsungnya kegiatan ekonomi. Muncul permukiman Cina yang baru di selatan (Kampung Karangturi).

Pembuatan jalan raya Anyer Panarukan yang dibuat Daendels pada tahun $1808 \mathrm{M}$, membawa perubahan pada arah perkembangan kota di Lasem. Keadaan ini membuat daerah pusat kota semakin berkembang. Permukiman Cina yang tadinya hanya di sekitar sungai mulai tumbuh ke arah jalan raya Lasem.

Pada masa penjajahan Belanda, terjadi pemberontakan anti Cina yang membuat populasi Cina di Lasem semakin membengkak dan menggeser permukiman pribumi ke arah timur. Kota Lasem menjadi kota ekonomi dan didominasi oleh permukiman Cina.

Perubahan yang terjadi setelah Indonesia merdeka adalah menurunnya populasi Cina di kota Lasem. Hal ini menjadi salah satu faktor kemunduran kota Lasem. Saat ini Lasem menjadi kota kecil yang tidak berarti. Aktivitas perdagangan sungai menjadi hilang. Rumah-rumah Cina sekarang hanya menjadi artifak dan penghuninya sudah banyak yang pindah ke kota lain (Hutama,1999).

Pembahasan mengenai pola spasial pada rumah tinggal tidak lepas dari pengaruh sosial budaya yang berkembang di wilayah tersebut. Untuk mengetahui lebih jauh prinsip-prinsip apa saja yang tetap dipertahankan dan yang mengalami perubahan pada rumah tinggal Cina di Soditan, Karangturi, dan Babagan Lasem.

Obyek yang diteliti adalah rumah tinggal Cina yang berada di wilayah Soditan, Karangturi, dan Babagan Lasem. Untuk lebih memahami perubahan dan kontinuitas pola spasial rumah Cina maka analisis hanya ditinjau dari aspek geometrik pada layout ruangnya saja.

\section{BAHAN DAN METODE}

Studi ini rumah Tinggal Cina di Karangturi Lasem dilakukan melalui observasi lapangan dan interview untuk memperoleh data-data mengenai rumah tinggal tersebut. Pengambilan obyek dilakukan secara purposive sampling. Untuk memahami dan mendeskripsikan pola ruang dalam organisasi ruang pada rumah tinggal Cina tersebut dilakukan analisis dengan menggunakan spatial syntax.

\section{Sejarah Pecinan di Lasem}

Menurut catatan sejarah dulu kota Lasem merupakan ibukota sebuah kerajaan yang cukup besar. Kerajaan Lasem dalam Negara Kertagama disebutkan bahwa Lasem sebagai kerajaan bawahan imperium Majapahit. Pada masa itu Lasem merupakan ibukota kerajaan sekaligus pelabuhan yang cukup besar. Lasem memiliki dua nukleus permukiman, di pesisir yaitu di daerah Caruban dan di pedalaman dengan pusatnya

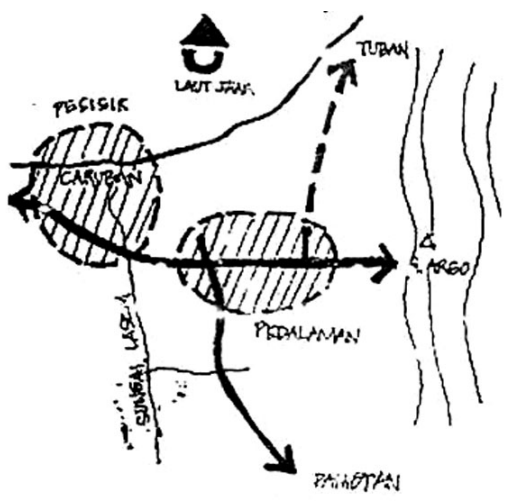

Gb.1. Dua nukleus permukiman di Lasem pada abad ke-14 M

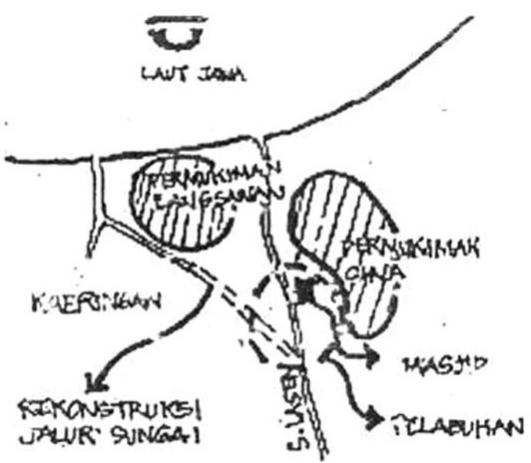

Gb.2. Permukiman bangsawan dan permukiman Cina berdampingan di wilayah pesisir Lasem 
di sekitar alun-alun. Dua nukleus permukiman ini mempunyai pola tatanan dan karakter yang berbeda. Permukiman di pesisir dihuni kelompok permukiman bangsawan dan permukiman Cina yang beragama Islam (Hutama, $1999: 2-4$ ).

Masuknya Islam di Lasem mengubah pola sosial budaya, konsep makrokosmosmikrokosmos yang berlaku pada Hindu-Siwa mulai sirna walaupun tidak sepenuhnya ditinggalkan. Perubahan ini juga terjadi pada masyarakat Cina di tepi sungai Lasem. Menurut catatan klenteng SamPoKong antara tahun 1450-1475 M masyarakat Cina di Jawa mulai menganut Konghucu dan masjid-masjid diubah menjadi klenteng, salah satunya di Lasem. Sungai Lasem tetap menjadi tempat berlangsungnya kegiatan ekonomi. Muncul permukiman Cina yang baru di selatan -kampung Karangturi (de Graaf dan Pigeud dalam Hutama, 1999 : 7).

Pada masa pendudukan Belanda membawa perubahan besar di Lasem. Pembuatan jalan Anyer Panarukan oleh Daendels pada tahun $1808 \mathrm{~m}$, menyebabkan daerah pusat kota semakin berkembang.
Permukiman Cina yang dulunya hanya di sekitar sungai mulai tumbuh ke arah jalan raya Lasem ini. Sungai mulai ditinggalkan dan sungai sebagai sarana perdagangan semakin jarang digunakan. Alun-alun menjadi pusat ekonomi baru, kegiatan ekonomi mulai berkembang ditandai dengan berdirinya rumah-rumah Cina yang berfungsi juga sebagai toko.

Pemberontakan anti Cina yang berlangsung beberapa kali menyebabkan permukiman Cina di kota Lasem semakin membengkak dan menggeser permukiman pribumi ke arah timur. Dibukanya kampung Gedong Mulyo dan Babagan oleh Belanda sebagai tempat untuk menampung masyarakat Cina menjadikan kota Lasem yang semula dikuasai pribumi berubah sebaliknya. Lasem menjadi kota ekonomi dan didominasi oleh permukiman Cina.

Kebijakan politik mempengaruhi kehidupan sosial budaya masyarakat Lasem. Kegiatan baik ekonomi dan budaya masyarakat Cina sangat dibatasi membuat masyarakat Cina menjadi terkucil. Hal ini menjadi salah satu faktor kemunduran kota

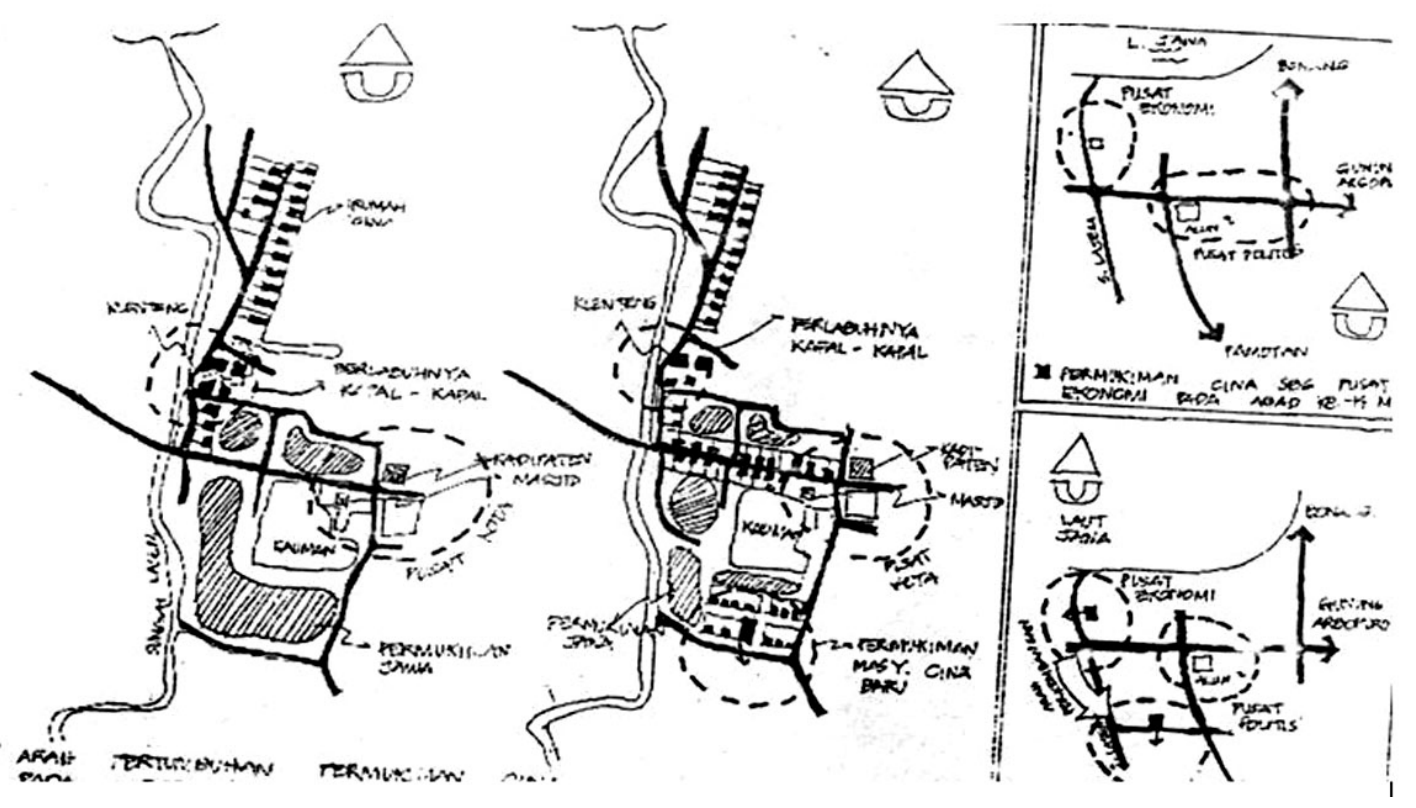

Gb.3. Perkembangan permukiman Cina pada abad ke -16 M di Lasem Sumber : Hutama, 1999 
Lasem. Saat ini Lasem telah menjadi kota yang tidak memiliki aktivitas perdagangan sungai. Rumah-rumah Cina yang ada sekarang hanya berupa peninggalan saja, penghuninya sudah banyak yang pindah ke kota besar.

Perkembangan rumah-rumah Cina dimulai dari pantai dan sepanjang sungai Lasem ke arah daratan. Kampung Cina pertama terletak di sepanjang sungai Lasem di Dasun ke arah selatan Soditan. Rumahrumah tersebut memiliki pintu masuk dan orientasi menghadap ke arah sungai.

Pembangunan jalan Anyer-Panarukan pada tahun 1808 oleh Daendels berpengaruh terhadap tata letak rumah-rumah Cina tersebut. Rumah-rumah tersebut pada akhirnya berorientasi menghadap ke arah jalan raya dan tidak menghadap ke arah sungai lagi. Jalan raya tersebut memicu tumbuhnya kampung baru di Karangturi dan Alun-alun di mana keduanya menjadi pusat pusat ekonomi yang baru.

Permukiman Cina di daerah Karang Turi (bagian selatan Lasem) termasuk permukiman yang berkembang setelah masuknya Islam ke daerah Lasem. Masuknya Kolonial Belanda di Lasem mengubah kehidupan sosial budaya setempat.

Bentuk rumah di Soditan masih berkarakter Cina dengan bentuk atap melengkung dengan konstruksi kayu dan kaya akan ornamen.
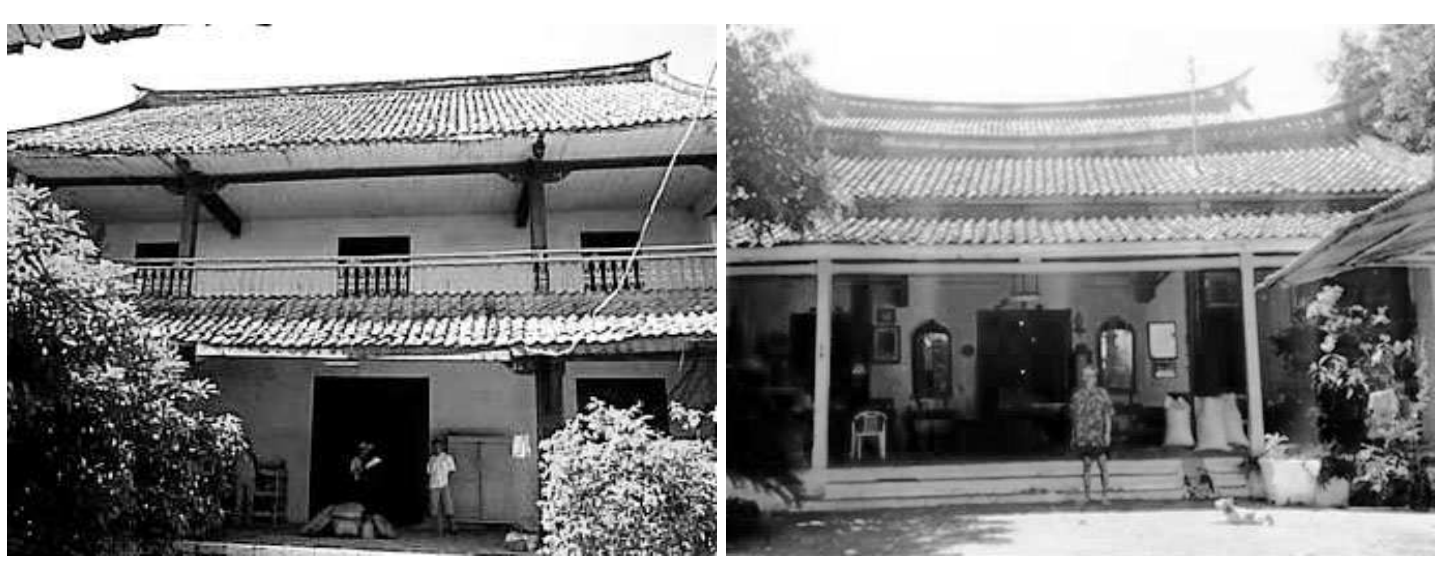

Gb.4. Tampak depan rumah Cina di Soditan 
Bentuk rumah di Karangturi ada yang memiliki gaya Eropa hal ini dapat dilihat pada antara courtyard depan dan belakang dihubungkan oleh lorong di sisi kanan dan kiri rumah. Lorong ini juga menghubungkan
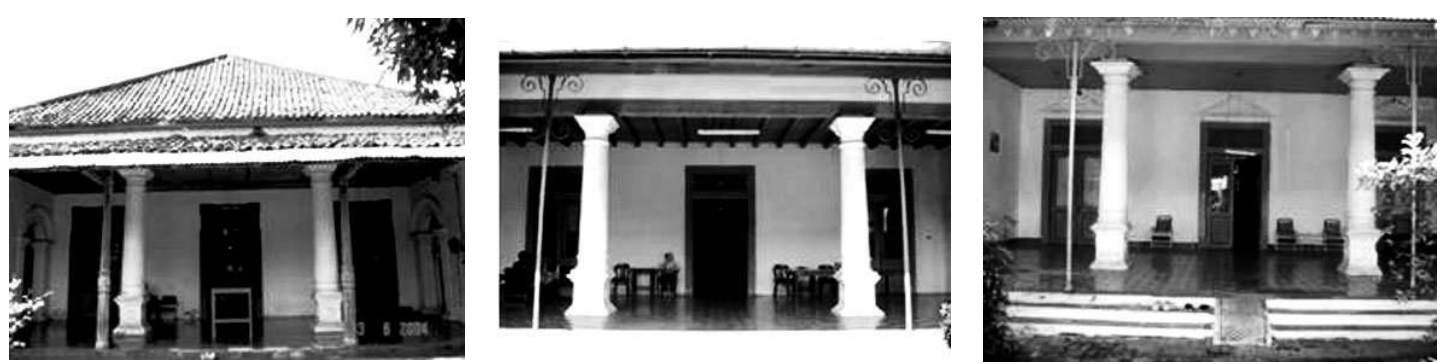

Gb.5. Tampak depan rumah Cina di Karangturi bergaya Eropa
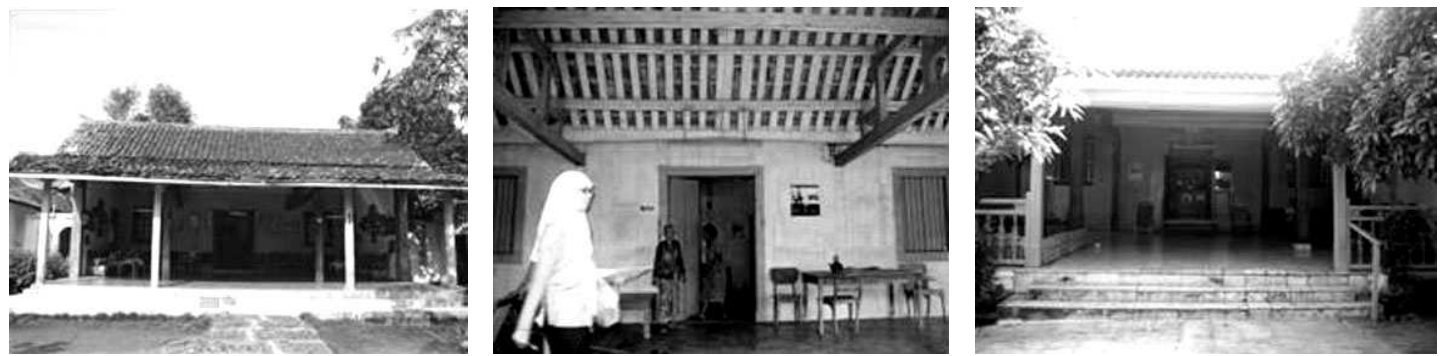

Gb.6. Tampak depan rumah Cina dari kayu (rumah geladak)

antara rumah dengan ruang servis.

Fasade bagian depan rumah memiliki komposisi yang selalui simetris dengan pintu di tengah dan diapit dua jendela. Pintu
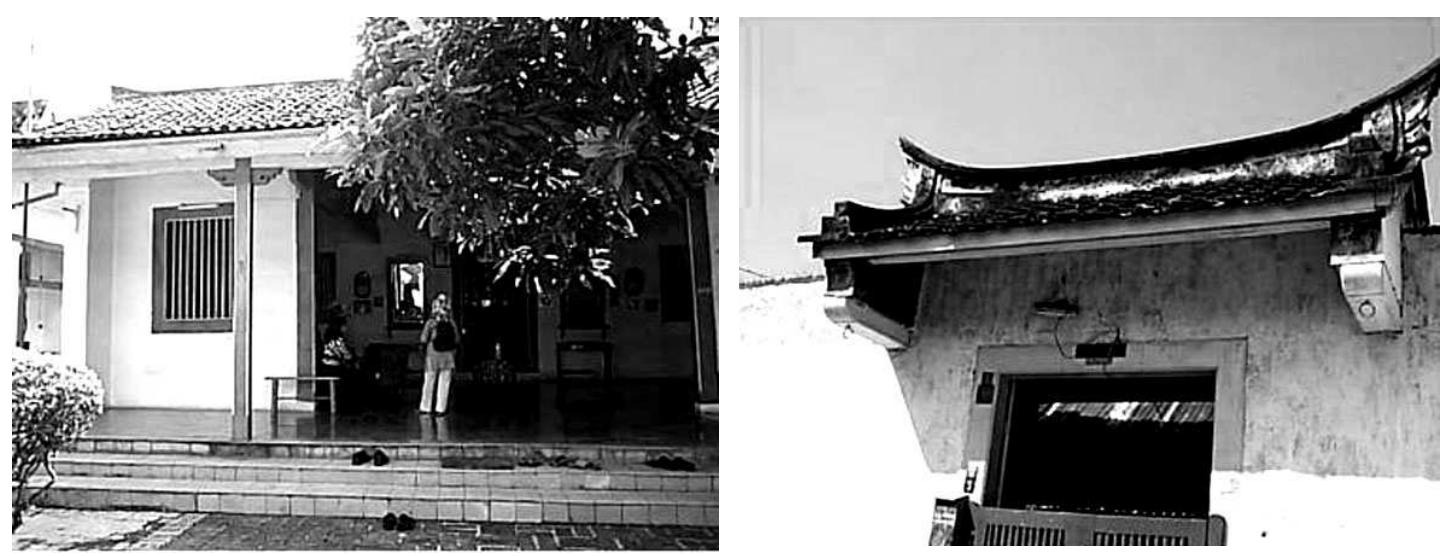

Gb.7. Tampak depan rumah Cina di Babagan 
UNTAS

RUANG | VOL.1 | EDISI 1 | 2007

tersebut menghubungkan antara teras dan ruang-ruang bagian dalam.

Ruang-ruang bagian dalam terdiri dari ruang duduk, ruang untuk sembahyang di mana tersimpan abu leluhur dari pemilik rumah tersebut yang letaknya bersebelahan dengan ruang keluarga. Di bagian sisi kanan dan kirinya adalah ruang tidur.

Bila mempelajari arsitektur rumah tinggal Cina yang ada di Indonesia, karakteristiknya hampir sama seperti ciri-ciri arsitektur Cina untuk rumah tinggal antara lain adanya halaman tengah (courtyard),

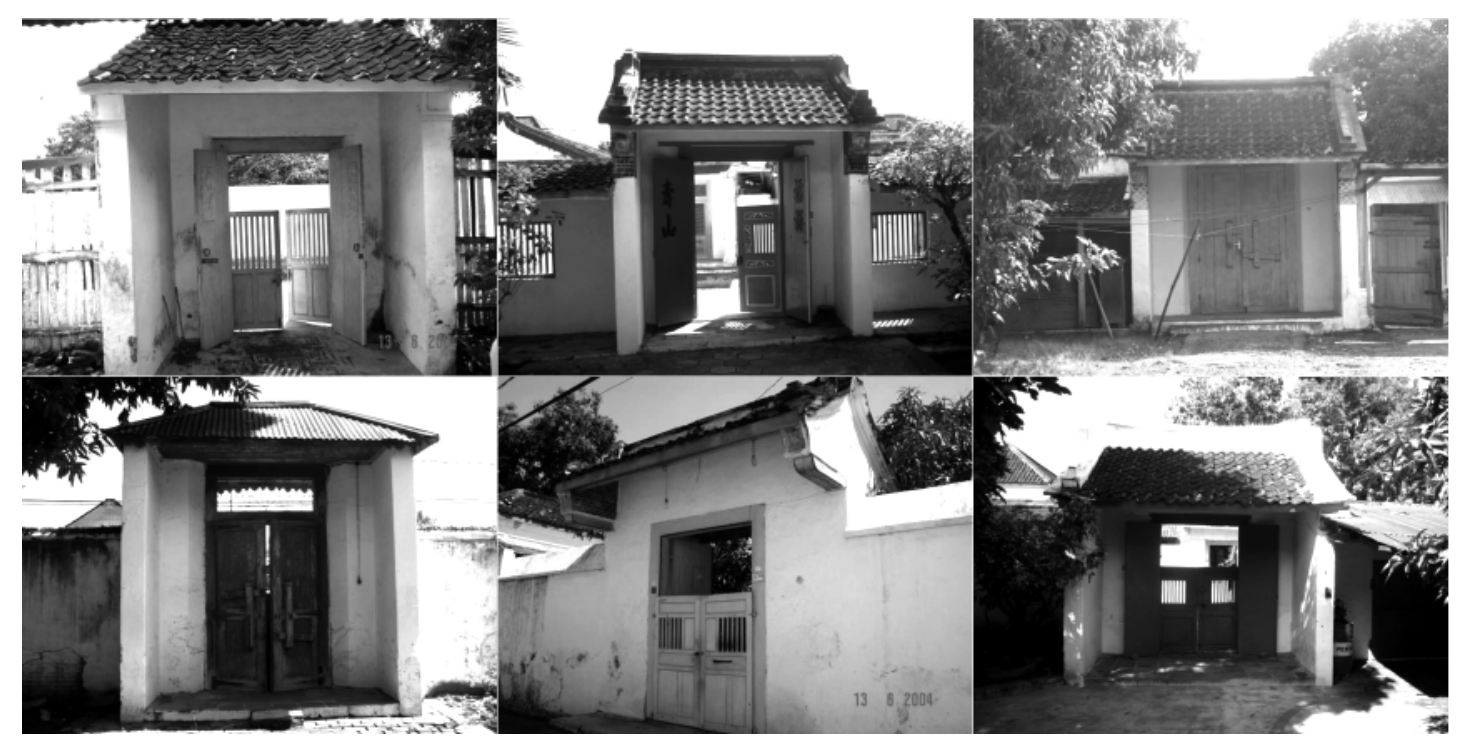

Gb.8. Pintu gerbang yang memiliki dua pasang pintu
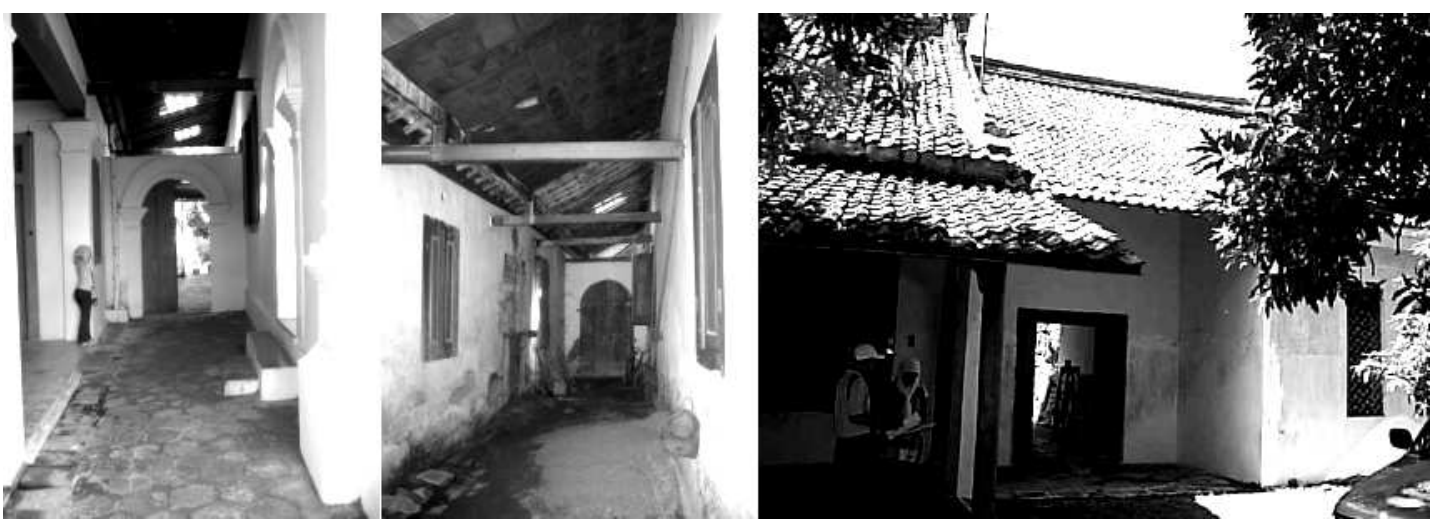

Gb.9. Lorong yang menghubungkan antara courtyard depan dan courtyard belakang, antara ruang dalam dengan ruang servis. 
penekanan pada atap, elemen struktur, dan penggunaan warna. Rumah tinggal di negara asalnya Cina mempunyai kontinuitas yang sangat panjang dan dibangun mengikuti konsep susunan ruang empat tangkap. Courtyard yang dikelilingi empat sisi ruang

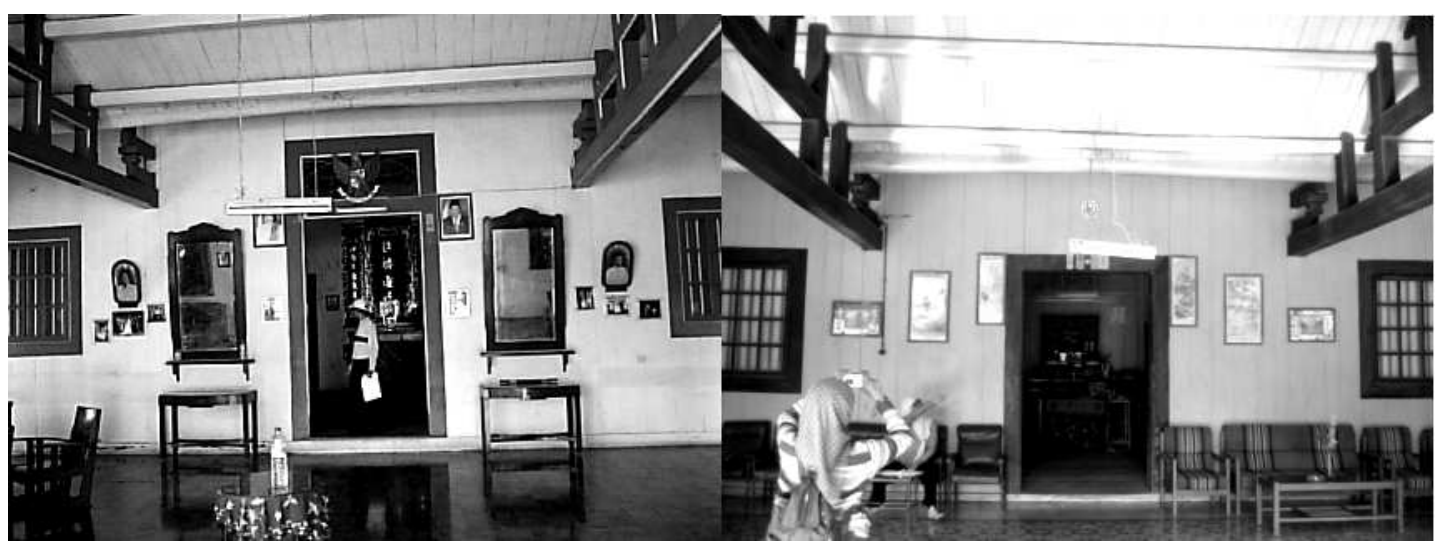

Gb.10. Fasade depan memiliki komposisi simetris

yang memiliki nilai makna tinggi. Fungsi courtyard adalah sebagai ruang peralihan, di mana semua ruang berorientasi ke arah courtyard tersebut.

Pada arsitektur rumah tinggal Cina menurut Steinhardt (1984), susunan ruang
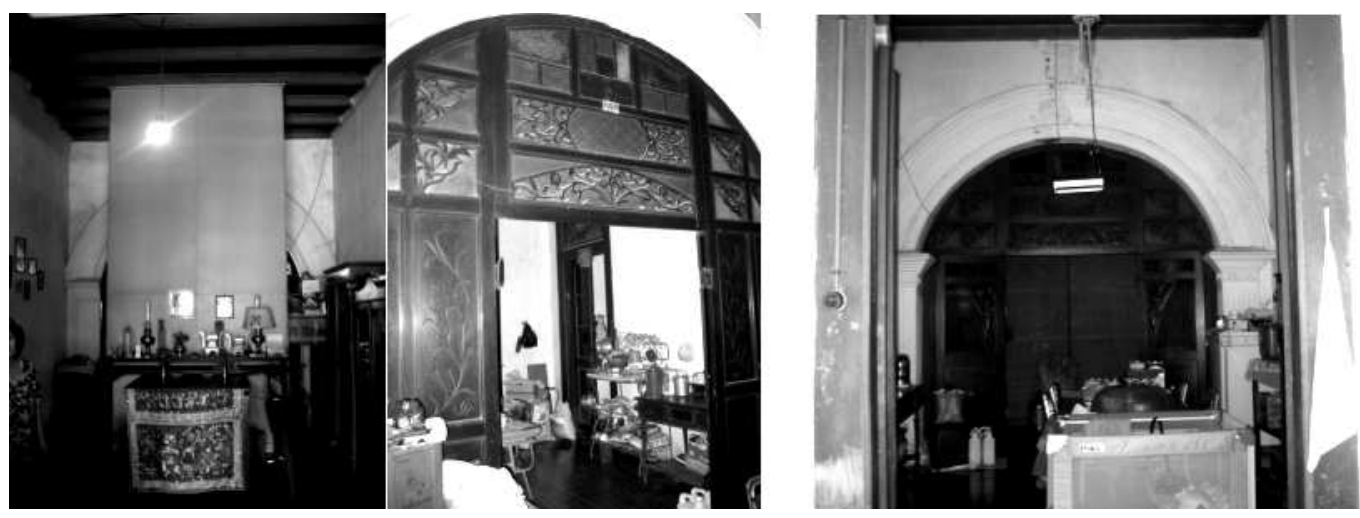

Gb.11. Ruang sembahyang untuk leluhur 
bersifat hirarkis di mana ruang yang diletakkan paling belakang merupakan ruang yang mempunyai nilai penting. Ruang depan diperuntukkan untuk menerima tamu, ruang tengah merupakan ruang tempat sembahyang untuk para dewa. Ruang ini juga digunakan untuk menerima tamu yang akrab. Ruang bagian belakang digunakan untuk hunian keluarga. Di dalam ruang tersebut juga terdapat tempat sembahyang bagi tamu yang akan menghadap tuan rumah dalam perayaan-perayaan tertentu. Ruang di sisi kiri dan kanan merupakan daerah servis. Ruang ini berhubungan dengan ruang depan dan ruang tengah tetapi secara ruang dipisahkan oleh courtyard.

Sebagaimana ruangnya yang disusun secara hirarkis berdasarkan nilai ruangnya, ornamennya juga demikian semakin ke belakang semakin kaya akan ornamen. Ruang tempat sembahyang memiliki ornamen yang paling lengkap.

\section{HASIL DAN PEMBAHASAN}

Pembahasan ini akan mengidentifikasi dan menganalisis ruang-ruang yang ada dalam organisasi ruang di rumah tinggal Cina Soditan, Karang Turi , dan Babagan Lasem menggunakan spatial syntax sehingga bisa ditemukan di mana letak perubahannya dan prinsip-prinsip apa saja yang tetap dipertahankan. Model sintak adalah metode yang digunakan untuk menemukan obyek terkecil atau struktur dasar dari sistem yang berlaku pada organisasi spasial yang memiliki keragaman dan mengetahui hubungan antar struktur dasar tersebut sehingga membentuk sistem yang koheren / saling bertalian (Hillier and Hanson, 1984 : 52).

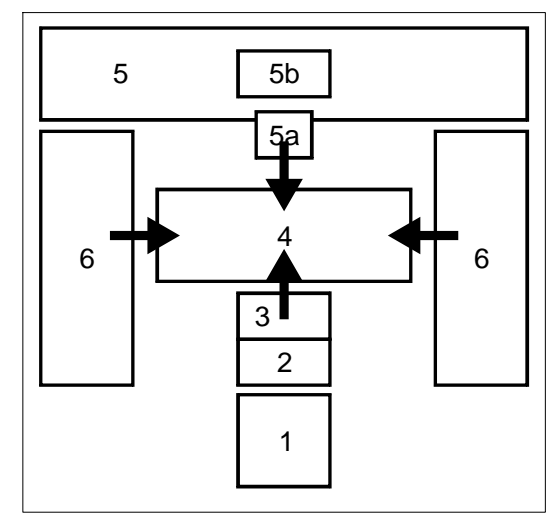

Gb.12. Susunan Ruang
Keterangan:
1. Halaman Depan
2. Ruang Tamu
3. Ruang Sembahyang Bagi Dewa
4. Courtyard utama
5. Hunian keluarga-ruang tidur
5a. Ruang keluarga
5b. Ruang sembahyang bagi leluhur
6. Daerah servis

Dari tabel di atas ditemukan bahwa rata-rata pola ruang memiliki empat level. Ruang A selalu terletak di level pertama dan Ruang D, E, G, dan $\mathrm{H}$ selalu terletak di level 4 (paling dalam). Ruang $\mathrm{A}, \mathrm{B}, \mathrm{C}, \mathrm{F}, \mathrm{I}$, dan $\mathrm{J}$ selalu terletak dalam dimensi lingkaran cincin.

Ruang-ruang yang selalu ada di setiap rumah tinggal Cina adalah ruang-ruang yang berada dalam dimensi lingkaran cincin : courtyard depan (A) saja atau courtyard depan dan belakang (I) menyambung dan tidak dibatasi pintu, teras depan (B), ruang sembahyang $(\mathrm{C})$, teras belakang (I) dan courtyard belakang (J) saja. Sedangkan faktor yang berubah-ubah terjadi pada variasi peletakan dan jumlah ruangnya seperti ruang 
Tabel.1. Kategorisasi Spasial Rumah Cina di Soditan

\begin{tabular}{|c|c|c|}
\hline No. & KASUS & SPATIAL SYNTAX \\
\hline K-1 & 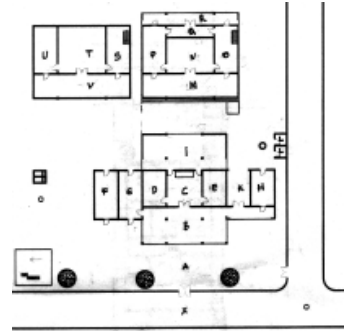 & (1) \\
\hline K-2 & 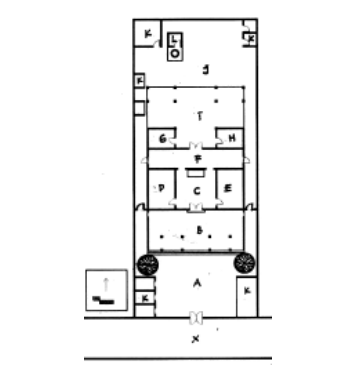 & (2) \\
\hline
\end{tabular}

Tabel.2. Kategorisasi Spasial Rumah Cina di Karangturi

\begin{tabular}{|c|c|c|}
\hline No. & KASUS & SPATIAL SYNTAX \\
\hline K-3 & 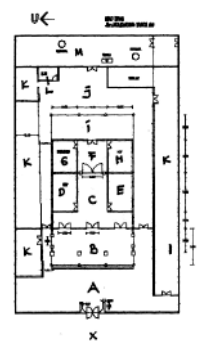 & (1) \\
\hline K-4 & 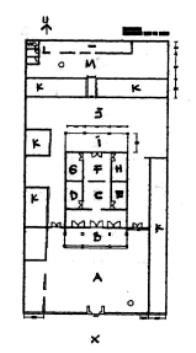 & (1) \\
\hline
\end{tabular}


$50 \quad \underset{\text { ISSN } 1978-0702}{\text { RINTAS }}$

Tabel.3.. Kategorisasi Spasial Rumah Cina di Karangturi

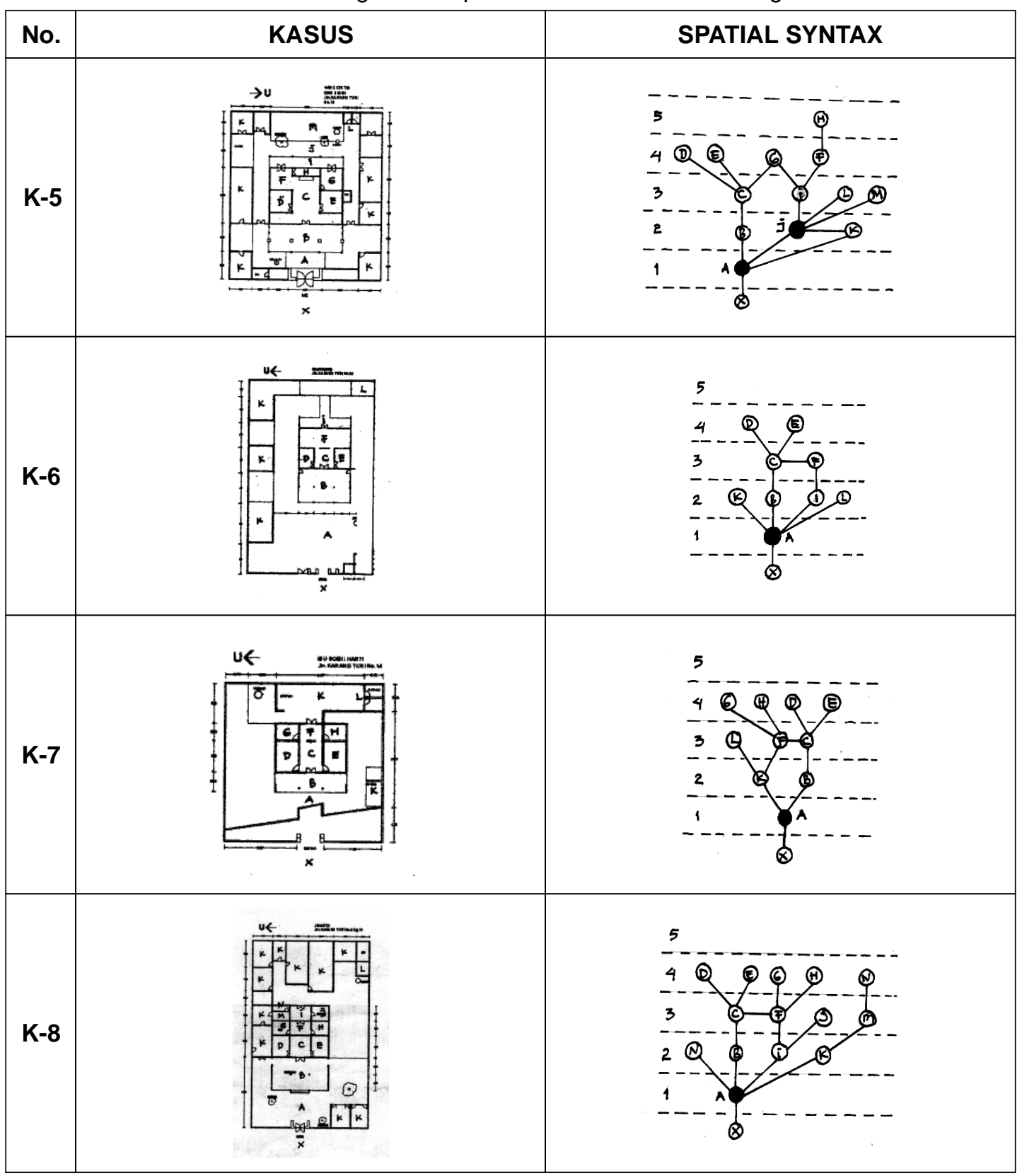


Tabel.4. Kategorisasi Spasial Rumah Cina di Babagan

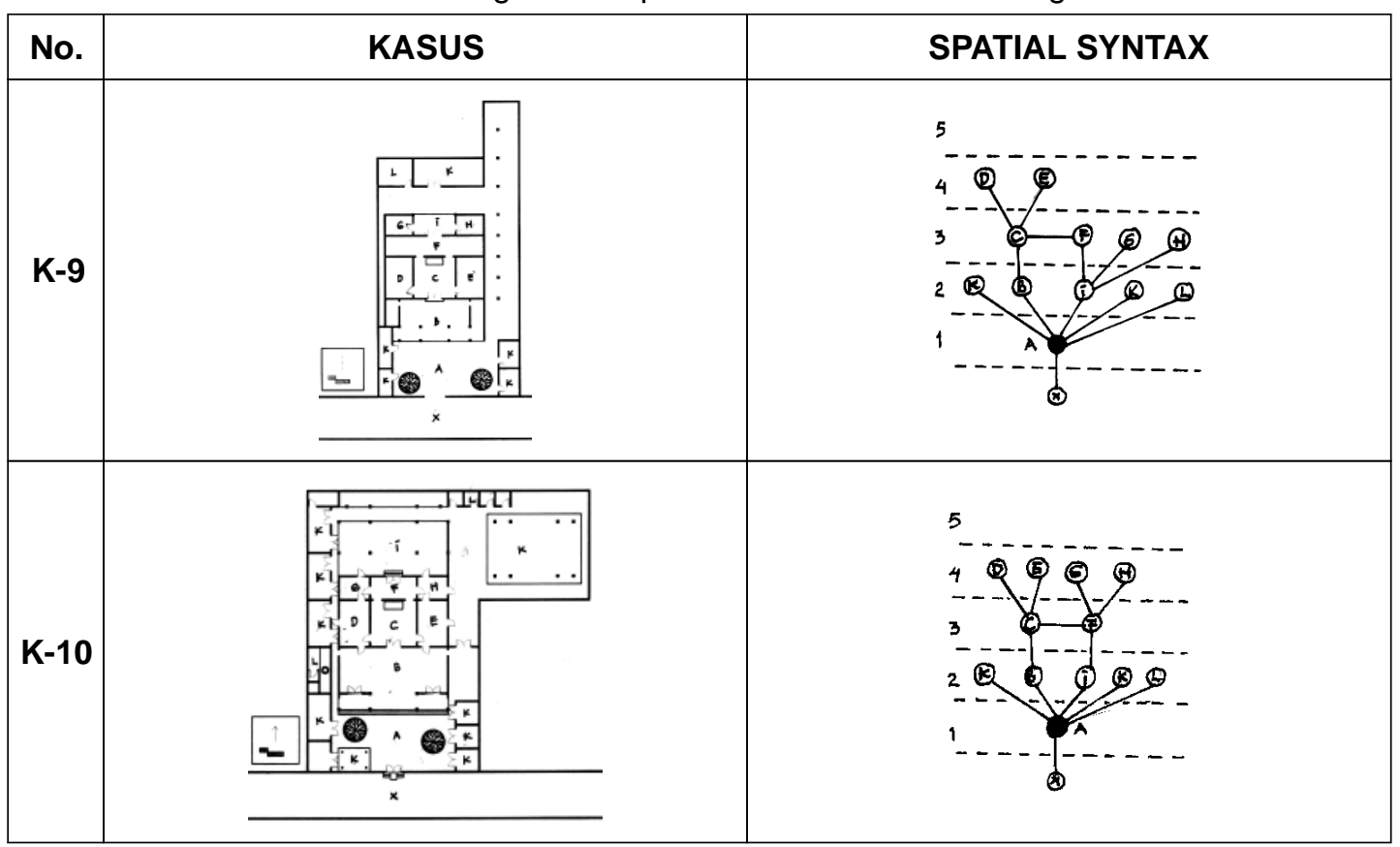

$\begin{array}{ll}\text { Keterangan : } \\ \text { ruang terbuka } \\ \text { ruang tertutup } \\ \text { jalan / ruang di luar site } \\ \mathrm{B} / \mathrm{I} & \begin{array}{l}\text { courtyard } \\ \mathrm{C}\end{array} \\ \mathrm{teras} \\ \mathrm{D} / \mathrm{E} / \mathrm{G} / \mathrm{H} & \begin{array}{l}\text { ruang sembahyang } \\ \text { ruang tidur }\end{array} \\ \mathrm{F} & \text { ruang keluarga } \\ \mathrm{L} & \text { ruang servis } \\ \mathrm{M} / \mathrm{N} / \mathrm{O} & \text { sumur/kamar mandi } \\ \text { ruang penyimpanan }\end{array}$

tidur, ruang servis dan sumur / kamar mandi.

Dari hasil analisis ditemukan bahwa terjadi perulangan pola utama yang sama pada rumah tinggal Cina di Karangturi, pola ini membentuk dimensi lingkaran cincin di mana di dalamnya terdapat enam ruang. Pola tersebut menunjukkan hubungan ruang yang simetrik dan terdistribusi . Jadi dapat disimpulkan bahwa terjadi kontinuitas pada pola spasial rumah tinggal Cina di Karangturi, Lasem.

Dalam bukunya Tao Teh Ching, Tao menyatukan Being (yang ada) dan Non Being (yang tak ada) ke dalam satu konsep yang terus bergema dalam seluruh perkembangan Manusia. Penyatuan dari dua kondisi yang berlawanan memang masih tetap menjadi struktur vital dalam estetika kontemporer 
yang berkaitan dengan ruang. Yang tidak nyata justru menjadi hakikatnya, dan dinyatakan dalam bentuk materi (Van de Ven, Cornelis, $1995: 3-8$ ).

Sesuai dengan pemikiran Tao tersebut ruang peralihan atau transisi ruang yang menghubungkan antara dunia di dalam dengan dunia di luar, direplikasikan dalam ruang courtyard (Adan J).

\section{DAFTAR PUSTAKA}

Hillier, Bill dan Hanson Julienne. 1984. The Spatial Logic of Space. Cambridge: Cambrigde University Press.

Hutama, David. 1999. Lasem Kota Yang Terlupakan. Tatanan. Volume 1 Nomer 1 Juli.

Steinhardt, N.S.1984. Chinese Traditional Architecture. New York: China Institute in America.

Van de Ven, Cornelis, 1995. Ruang Dalam Arsitektur. Jakarta: PT Gramedia Pustaka Utama.

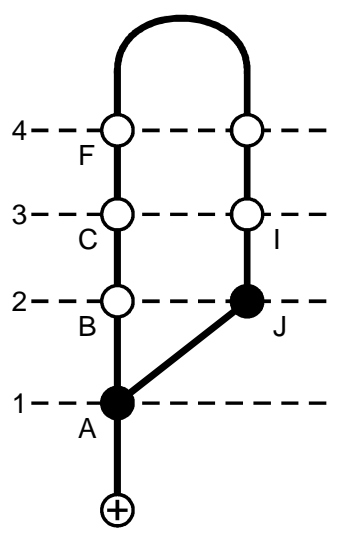

Gb.13. Pola Spasial

Keterangan:

Ditinjau dari hirarki ruang maka ruang $\mathrm{C}$ menduduki hirarki yang paling tinggi karena untuk mencapai ruang tersebut baik dari depan maupun belakang harus melalui tiga tahap (tiga ruang). Hal ini juga menunjukkan bahwa privasi yang tinggi dan keamanan yang berlapis menjadi pertimbangan utama dalam pola ruangnya. 